\title{
On the Authors
}

\section{Dr. Gunter Lösel}

heads the Research Focus "Performative Practice" at the Zurich University of the Arts, developing models for artistic research in the performing arts. With a background in psychology and in acting, his research interests comprise embodied cognition of acting, collaborative practices, and improvisation. In the SNSF project Research Video he is a principal investigator.

\section{Prof. Dr. Martin Zimper}

is Head of "Cast/Audiovisual Media" at Zurich University of the Arts, researching and lecturing on transmedia arts/ digital narrative. He is a member of the Academic Steering Committee of Media Technology Center (ETH Zurich) and a lecturer on digital storytelling at the University of St. Gallen (HSG). He is coapplicant in the SNSF project Research Video.

\section{Martin Grödl \& Moritz ResI}

founded Process, an experimental design studio based in Vienna that specializes in generative and interactive design and works in the fields of branding, web, installation, and print. As well as traditional graphic design solutions, Process designs and develops highly specialized software that is used as tools for and by clients. In this project they were responsible for concept, design, and development of the Research Video tool.

\section{Léa Klaue}

is a visual anthropologist and $\mathrm{PhD}$ candidate at the Institute of Social Anthropology of the University of Bern; She is also a research associate working on the Research Video project at the Institute for Design Research/Zurich University of the Arts. In her PhD project she conducts research about independent working children in urban Bolivia while using audiovisual ethnographic methods. Her thesis navigates between documentary and fiction short films and anthropological text.

\section{Eric Andreae}

studied directing at the University of the Arts in Zurich (ZHdK). Since 2010 he has worked as a research fellow at the university and since 2019 he has been an associate professor in the "Cast/Audiovisual Media" department. In addition, he works as a freelance director for TV and commercial productions. In the Research Video project, he focuses on video production methods.

\section{Marisa Godoy}

is a dance researcher, teacher, and award-winning artist based in Zurich. Her creative practice involves stage productions, video installations, and performances in alternative spaces, mostly under the label OONA project, performed in festivals in Switzerland as well as internationally in the UK, France, Germany, South Korea, among others. She is a research associate at Institute for the Performing Arts and Film (IPF)/Zurich University of the Arts (ZHdK), as well as a PhD candidate at C-DaRE/Coventry University. 